\section{Er dette nok?}

Kronikken Ta faget tilbake! (1) behandler viktige problemer. Dessverre er det ikke samsvar mellom problemene som presenteres, generelle ønskemål og spesifikke løsningsforslag. Kjente styringsproblemer blir dessuten forbigått.

Økende byråkrati tar vekk ressurser fra pasientbehandlingen. Dette er dog ikke spesifikt for helsevesenet, vi ser det i både offentlig og privat virksomhet, uavhengig av styringsform. Den økonomiske styringsmodellen new public management (NPN) får mye av skylden. Ifølge professor Jan Grund var new public management 1980- og 90-årenes styringsideologi, i dag har vi allerede en mer pragmatisk styringsform (2).

Samfunnet bestemmer totalrammene til helsevesenet via en politisk prosess. Innenfor disse rammene må det prioriteres. Diskusjonen handler om hvem som skal prioritere på alle nivåer og hvordan fordelingen skal styres. I dag er dette et forvaltningsansvar, altså et byråkrati, der de regionale helseforetakene er forvaltningsorganer. Denne modellen har sørget for likebehandling av regionene. De problemer man ser i dag i Oslo-prosessen, er ikke nødvendigvis representative for andre regioner eller uttrykk for systemsvikt. De bunner heller i sviktende premisser og dårlig ledelse på flere nivåer. Og med sykehusstyrene har vi heldigvis ikke lenger fylkeskommunene, der sykehusdrift måtte konkurrere med andre sektorer.

I kronikken lanseres «demokratisk underskudd» som et problem. Et profesjonsstyrt helsevesen er teknokrati. Det kan muligens være en faglig fordel, men demokrati er det ikke! Og det vil si at profesjonene må ta mer ansvar for den overordnede prioriteringen. Ansvar på grunnplanet, altså en «delegering av ansvaret nedover», har de allerede. Sier man ja til noe, sier man nei til noe annet. Er man «snill» og lar én pasient ligge en dag lenger, må en annen ut tidligere. Ansvar for den individuelle pasient løser ikke dette alene. I et profesjonsstyrt helsevesen er det også stor mulighet for at faggruppene vil prioritere egne pasienter, mens det overordnede fordelingsansvaret forsvinner - prioriteringer blir et resultat av spesialitetenes gjennomslagskraft. «Åpenhet» om driftsproblemer kan også degenerere til elendighetsbeskrivelser i mediene, brukt $\mathrm{i}$ interne kamper om midler. Dette kan igjen gå utover andre pasientgrupper. Noen pasienter vil alltid være mer «lønnsomme» enn andre. Hvilke varierer med styringssystemet, men en omlegging vil kunne flytte problemet heller enn å løse det.

Nedbygging av byråkrati kan frigjøre ressurser til pasientbehandling, men løser ikke problemet med prioriteringer og fordeling. Det trengs kulturbygging basert på verdier og faglighet. Samarbeid mellom profesjoner kommer heller ikke av seg selv, vi har hatt nok av profesjonsstrid. Kulturen må også bygge på forståelse av helheten, der man godtar prioriteringer også når det rammer eget fagfelt. Dette må da være ledelsesforankret. Hvis nedbygging av administrasjon fører til fravær av ledelse, nærmer vi oss et system der prioritering skjer på basis av maktkamp, altså et anarki.

\section{Asbjørn Støylen}

asbjorn.stoylen@ntnu.no

Asbjørn Støylen (f. 1956) er professor i kardiovaskulær fysiologi ved Institutt for sirkulasjon og bildediagnostikk, Norges teknisk-naturvitenskapelige universitet, og overlege ved Hjertemedisinsk avdeling, St. Olavs hospital. Ingen oppgitte interessekonflikter.

\footnotetext{
Litteratur

1. Wyller VB, Gisvold SE, Hagen E et al. Ta faget tilbake! Tidsskr Nor Legeforen 2013; 133: 655-9.

2. Lindvåg D. Helseprofessor vil slåss for revmatikerne. Fysioterapeuten 2013; nr. $2: 8-10$
}

Dette er en redigert versjon av et innlegg publisert som rask respons i nettutgaven 2.4. 2013. http://tidsskriftet.no/article/2987819/

\section{T. Bruun Wyller svarer:}

Vår kronikk om styringsideologien i norsk helsetjeneste (1) har vakt en storm av reaksjoner. Vi takker for alle de 11 innleggene som er publisert her - vi tror de på en god måte illustrerer spekteret av reaksjoner vårt initiativ er blitt møtt med. Et stort flertall synes å være begeistret og takknemlig for at noen tar bladet fra munnen og «setter ord på det vi alle mener». Samtidig reises det selvfølgelig også spørsmål og innvendinger som fortjener videre diskusjon. Konstruktiv kritikk og forslag er nødvendig for å finne løsninger. Plassen her gir ikke rom for å svare i detalj på alt. Mye har vi allerede drøftet $i$ artikler vi har publisert den siste måneden (2-4).

Vi tror det ville vært naivt om vi hadde ambisjoner om å beskrive en ny styringsmodell i detalj. Vi vet bedre enn noen at helsetjenesten er så komplisert at den ikke kan planlegges av en liten gruppe helsearbeidere på fritiden. Vi har derfor i denne omgang nøyd oss med å beskrive noen tiltak som vi mener er nødvendige, men langt fra tilstrekkelige for å få helsetjenesten på en riktigere kurs. I tillegg har vi beskrevet de fagetiske prinsippene som vi mener er helt avgjørende forutsetninger for en god og verdig helsetjeneste.

Kronikken førte til at vi fikk tilslutning fra helsearbeidere utenfor legenes rekker. Vi er overbevist om at i kampen for en menneskelig og pasientsentrert helsetjeneste, må helseprofesjonene stå sammen. Vi må også søke allianse med pasienter og pårørende, våre egentlige oppdragsgivere.

Som en direkte oppfølger av kronikken har vi etablert Helsetjenesteaksjonen (5), som er en tverrfaglig sammensatt aksjonsgruppe. Vi forventer at vi må kjempe lenge for oppnå endringer i den retningen vi mener er nødvendig, uansett hvilke partier som sitter med regjeringsmakten. Derfor vil vi bygge opp en aksjon som er tilstrekkelig robust til at den kan være aktiv og søke påvirkning og innflytelse over lang tid. Helsetjenesteaksjonen er ingen medlemsorganisasjon, men består av en aksjonsgruppe (5) som arbeider med kronikken (1) som prinsipprogram og ideologisk plattform. Interesserte kan tegne seg på en nyhetstjeneste (5), der vi fortløpende orienterer om fremdrift og planlagte tiltak.

\section{Torgeir Bruun Wyller}

t.b.wyller@medisin.uio.no

Torgeir Bruun Wyller (f. 1960) er professor i geriatri og overlege. Han leder Helsetjenesteaksjonen.

Ingen oppgitte interessekonflikter.

\section{Litteratur}

1. Wyller VB, Gisvold SE, Hagen E et al. Ta faget tilbake! Tidsskr Nor Legeforen 2013; 133: 655-9.

2. Kirkevold $M$, Holter IM, Burås-Leine $C$ et al. Gjenreis helsefagenes verdigrunnlag! Sykepleien 2013; nr. 5: 64-5.

3. Kirkevold M, Nereng MK, Thomsen I. Hva står vi for? Morgenbladet 19.4.2013. http://morgenbladet.no/debatt/2013/hva star vi for (30.4.2013)

4. Gisvold SE, Kirkevold M. Helsetjenesteaksjonen - hvem venter vi på? Dagens Medisin 29.4.2013. www.dagensmedisin.no/debatt/helsetjenesteaksjonenhvem-venter-vi-pa (30.4.2013).

5. Helsetjenesteaksjonen. www.helsetjenesteaksjonen.no (30.4.2013). 